\title{
14 Trauma in Translation
}

\author{
Liao Yiwu's "Massacre" in English and German
}

Rui Kunze

\begin{abstract}
This essay traces various cultural translations of Liao Yiwu's poetry into English and German. It foregrounds a tight entanglement of literature and politics that starts with the suppression of the 1989 Protest Movement in China and extends to a dynamic engendered by publishers, prize-giving bodies, and prestigious cultural figures abroad. It reveals the complexities of communicating trauma between East and West and the gripping textual traces that are left in the process.
\end{abstract}

Keywords: Chinese poetry, translation, Liao Yiwu, cultural translation, trauma, poetry performance

Fuling, a river town in Sichuan province, June 4, 1989. Poet Liao Yiwu 廖 亦武 (b. 1958), a rising star on the late 1980 s poetry scene, recites sections three and four of his long poem "Slaughter" (屠杀). He does this at home, for an audio tape recorder, in the presence of two close friends, Canadian student of sinology Michael Day and fellow poet Li Yawei 李亚伟.

Liao and Day had seen soldiers patrolling in Fuling on June 1, when Day arrived from Beijing to stay at Liao's house. In the evening of June 3 , at home, Liao completed sections three and four of "Slaughter" under unbearable inner pressure. Then Day, who had been outside, came back to his house, and Li Yawei joined them later. At six a.m. the next morning, after a night filled with scattered news about the killings that are remembered as June Fourth (六四), when the army broke up the student-led pro-democracy and anti-corruption protests in Beijing and other cities in China, Liao finished recording his performance of the poem. He made three copies of the original tape and labeled them “The Era of Protest” (抗议的时代). He gave the copies

Van Crevel, Maghiel and Lucas Klein (eds.), Chinese Poetry and Translation: Rights and Wrongs. Amsterdam: Amsterdam University Press, 2019

DOI: $10.5117 / 9789462989948 \_C H 14$ 
to Day, who would be traveling to other parts of China, for him to share the poem with others.

This is Liao's recollection of these fateful days, as recorded in his memoirs $(2003,2004 a, 2011)$. (Detailed letters Day wrote to a friend at the time indicate that Liao was still working on the poem on June 6 and finished it around June 10, and that the recording did not take place until June $18 ;{ }^{1}$ while this discrepancy highlights the complexity of the phenomenon of memory in theory and practice, it does not essentially affect the argument made in these pages. We will revisit it later.) In March 199o, Liao was arrested and sentenced to four years in prison for counter-revolutionary propaganda and agitation, one of several Sichuan poets who were jailed after June Fourth (Day 2005, 348-349). Day was expelled from China in November 1990.

There was a recent collective memory of using poetry recitation for protest and mourning. On April 5, 1976, during the annual Tomb-Sweeping Festival for honoring the dead, thousands had recited poetry on Tiananmen Square when mourning premier Zhou Enlai, to voice their discontent with the government. Zhou had passed away in January and was widely seen as a counterweight to egregious political trends during the Cultural Revolution (1966-1976). Those who were then arrested as "counter-revolutionaries" were rehabilitated in 1978, and an anthology of the poetry associated with what became known as the Tiananmen Incident was published by the People's Literature Press (Tong 1978).

Just like the 1976 demonstrations, the 1989 protests began with the mourning of a popular political figure on the square - this time Hu Yaobang 胡耀 邦, who had died in mid-April - but they lasted for seven weeks and were incomparably larger in scope, triggering student and civilian protests in various cities all over the country. The crackdown started in the early hours of June 4 in Beijing, with estimates of the death toll ranging from several hundreds to several thousands. It expanded into a nationwide purge in subsequent years, with targets including public intellectuals and those in cultural circles. While Chinese and foreign citizens and institutions have advocated for public debate on June Fourth ever since, references to the event and its victims continue to be censored in China. Along with a general sentiment of depoliticization that has accompanied the country's radical economic liberalization since 1992, this has made June Fourth, often coded as "1989," a contested site of memory politics. All the more so because it was televized real-time by media around the world, just like the various more successful protest movements in that fateful year elsewhere 
in the world, which led to the disintegration of the Eastern bloc and shook the communist narrative worldwide.

Liao Yiwu's life was permanently changed by June Fourth. When he left prison in 1994, he was doubly disenfranchised, from the poetry scene and from society. He turned to non-fiction writing, in which he recorded the life stories of subalterns in Chinese society, but suffered constant surveillance and harassment by the police, who regularly confiscated his manuscripts. In July 2011 he fled to Germany, where he has lived in exile since, and received various literary prizes, including the 2011 Geschwister-Scholl Prize, named after two anti-Nazi activists, and the 2012 Peace Prize of the German Book Trade. The jury of the latter called him a "people's writer" who stands for "human dignity, freedom, and democracy."

Despite Liao's shift from poetry to non-fiction, "Slaughter," later known as “Massacre” (大屠杀), which is how I will refer to it from here on, has remained at the center of his literary biography, as a turning point in his life and the subtext of his later non-fiction writing. The poem has four sections. Liao appears to have completed sections one and two in May 1989 and originally conceived the poem, together with two other long texts from 1988 , as part of a trilogy in which he meant to criticize "the simultaneous physical and spiritual 'slaughter' of Chinese civilization" (Day 2005, 349350). In Liao's typically verbose style, the speaker in sections one and two of "Massacre" expresses shock, confusion, and resentment in the face of rampant commercialism in late 1980 os China, a theme many other authors were addressing as well. Leaving the exact date aside, it is clear that sections three and four were completed in June 1989, writing of and responding to "an all too real slaughter" (Day 1992c, 50). Section three is a polyphonic text portraying a panicky, chaotic scene, where an army follows order to kill defenseless civilians. Section four features the speaker reflecting on the need to retain the historical memory of violence, its perpetrators, and its victims. Often presented as a single text, sections three and four have come to be known as the text of "Massacre" in the course of time.

In this essay, I attempt to demonstrate that trauma plays a key role in the cultural translation of "Massacre." I argue that both "Massacre" and Liao's memoirs - which address his creation and performance of the poem - are texts produced in response to his personal trauma of June Fourth; and that their translations across media and cultures in English and German contexts show Liao interacting with other agents in the translational process to construct various narratives of this personal trauma, which in their turn feed into the construction of June Fourth as a cultural trauma in the larger post-1989 world. 


\section{Trauma and cultural translation}

Drawing on Freudian psychoanalysis, Cathy Caruth's work on narrative and history characterizes trauma as a compulsively recurring experience of the survivor, whose narrative of "a belated experience" of suffering bears the impact of the event's "incomprehensibility" (1996, 2, 6, 7). The connection between a traumatic narrative and the historical event that underlies it therefore lies in indirect referentiality: "For history to be a history of trauma means that it is referential precisely to the extent that it is not fully perceived as it occurs, or ... that a history can be grasped only in the very inaccessibility of its occurrence" (18). Thus narrating (personal) trauma reveals, according to Michael Berry, "a crisis of representation" (2008, 17, citing Joshua Hirsch).

Recent studies link personal trauma to more general sociopolitical conditions and gesture towards a cross-cultural perspective for understanding history through the prism of personal trauma. Michael Rothberg has proposed to study anachronistic and anatopic (dis)placements of trauma in literary works so as to bring together different traumas "as singular yet relational histories" with a multidimensional memory. This method, Rothberg says, can develop "differentiated maps of subject position and experience" and theorize "the differentiated ... landscapes of violence" (2008, 225, 231, 232), which may help "reconceive the link between cultures" through trauma (227). Following Slavoj Žižek's application of Lacanian trauma, Sebastian Liao (2014) argues that the debates on translating European literary modernism into Chinese poetry in the twentieth century are symptomatic of China's traumatic encounter with various colonial powers.

Against the backdrop of these various theorizations of trauma, the present essay adopts Jeffrey Alexander's distinction of personal trauma and "cultural trauma." Alexander presents cultural trauma as the result of a social process of constructing narratives of sufferings (2004). It occurs "when members of a collectivity feel they have been subjected to a horrendous event that leaves indelible marks upon their group consciousness, marking their memories forever and changing their future identity in fundamental and irrevocable ways" (1). Cultural trauma is therefore a "master narrative of social suffering" (15). By way of an example, Alexander outlines a transformation in the (American) construction of the mass killings of Jews in World War II, from a specific, situated war crime to a universalized symbol of human suffering and moral evil. He identifies two narrative modes in different phases of the process: a "progressive" narrative that sees Nazi anti-Semitism as a locally situated war crime that was overcome by the allies, and a "tragic" narrative developed later that sees barbarism lodged in modernity, with 
everyone as potential victim and perpetrator (227-229). As protagonists the progressive narrative features the liberating hero (e.g. the American GI), while the tragic narrative involves those who are "in the grip of forces larger than themselves, impersonal, even inhuman forces that often are not only beyond control but, during the tragic action itself, beyond comprehension" (226). Alexander argues that the universalization of the Jewish genocide into "a traumatic event for all of humankind" (197) requires, among other things, its dramatization across media to create a sense of identification on the part of the audience, by appealing to the affective and the experiential.

Alexander's example implicitly involves cultural translation. Two of three categories of cultural translation as summarized by Maghiel van Crevel are particularly useful here: "culturally inflected interlingual translation" and "the general activity of communication between cultural groups" (2017, 247-248). The notion of cultural translation can thus be used to examine power relations and legitimacy in translational practices at multiple levels. We can study not just the "movement of meaning" (Bhabha 1994, 228) in the individual translator's choices at the textual level; but also, at the metatextual level, the role of discourses and institutions in cultural communications. This resonates with Doris Bachmann-Medick's suggestion of considering the "translational collective," namely not just the mediating practices of the translator but also "the whole chain of translations via institutions, instruments, and technical conditions," which have an equally active mediating function $(2014,129)$.

Below, I first sketch the production and circulation of "Massacre" in relation to various versions of Liao Yiwu's memoirs (Chinese, English, and German), arguing that it is an unstable source text whose changes, coupled with its different contexts, create different narratives of Liao's personal trauma as well as different interpretations of the poem itself. I then try to demonstrate that both Liao's personal trauma and the phenomenon of cultural trauma are at work in the interlingual translators' renditions of "Massacre." Next, I analyze five examples of the transmedial performance of "Massacre" in different linguistic and cultural contexts, showing concretely how the poem-in-performance travels from expressing personal trauma to constructing cultural trauma.

\section{The source text on the move: from "Slaughter" to "Massacre"}

Liao Yiwu has published, reworked, and republished his memoirs over the years, in Chinese and in translations into English and German among other 
languages. In Testimonies: Speaking for China's Subalterns (證詞: 為中國底 層賤民代言, 2004a) published by the US-based Mirror Books, he changes the poem's name from 屠杀 'slaughter' to 大屠杀 'massacre', a term that conjures large numbers of deaths and great historical significance. While in the main text, the third and fourth sections of the poem are presented under the title "Slaughter," in paratexts such as photograph captions (248), Liao's curriculum vitae $(487,489,490)$, and the book's inside back cover, the poem is referred to as "Massacre." I agree with Day $(2005,349 n 624)$ that this was likely the first time the title was changed in print. Keeping "Slaughter" for the main text may have been in order to retain the factuality of the ur-story, but at the same time the switch to "Massacre" in the paratexts signals Liao's intention to posit June Fourth as a cultural trauma that far transcends his personal story - also by implying its comparability to the Holocaust, often rendered in Chinese as the "Massacre" (大屠杀) as well. Later, the change would lead to the English and German translations of the title as "Massacre" and "Massaker," respectively.

On the 2010 anniversary of June Fourth, Liao Yiwu published the poem's full text in Chinese as "Massacre" on the website Free Writing (自由写作), an online platform of the Independent Chinese PEN center, founded by Chinese-language writers in exile in 2001. This is, to my knowledge, the single publication of the Chinese source text that comprises all four sections of the poem. The first two sections were partly translated by Day in his 2005 dissertation. As mentioned above, it appears they were written in May 1989, after Liao visited Beijing in March and April together with Li Yawei (Day 2005, 350; Liao 2011, 49). The beginning of section one addresses an elevated and (self-)tormented misfit. In Day's translation:

\section{Cry! Cry! Cry! Cry! Cry!}

The only person this century to squander his tears

The only person this century to soar beyond mankind

The only person this century with the courage to obstruct the tide of history Crycrycrycrycrycrycrycrycry!

$(2005,350)$

As the text runs on, the misfit addressed as "you" turns out to be a poet, and an alter ego of the speaker (to whom I will refer with male pronouns, in light of the linkage of the text to Liao Yiwu's personal experience, as explicitly identified by himself). "You" is compared to tragic poet-hero figures from Chinese antiquity such as the exiled official Qu Yuan 屈原 
and the rebellious general Xiang Yu 项羽 - both expressed in verse their bitterness over not being acknowledged by their contemporaries (and both committed suicide). The speaker laments that "you" suffers similarly:

Too bad nobody knows you. The fasting, petitioning students don't know you. The capital under martial law and the soldiers don't know you.

(Day 2005, 351)

These sentences echo Liao's own experience in Beijing in March and April 1989, when he did not feel welcome. As he describes in his memoir, with a touch of irony: "Since poetry and recitation could not conquer the capital, we ... returned to Fuling indignant and bitter" $(2011,49)$.

In Fuling, Liao wrote sections three and four. In Chinese, they appear in full in all three published versions of his memoirs: Catastrophe: An Individualistic Testimony around the Year 1989 (天劫 - 八九前后的个人 主义证词, 2003, 14-16), the aforesaid Testimonies (2004a, 41-45), and the latest - and perhaps the fullest - version, June Fourth: My Testimony (六 四: 我的證詞, 2011, 61-65). ${ }^{2}$ Section three starts, in verse, with the speaker describing the order given to soldiers to kill. The text then switches to what is best described as stream-of-consciousness prose, with the voices of soldiers delirious from the act of killing mixing with those of helpless victims, living and dead, who are begging for mercy. Section four returns to verse, where the speaker urges his alter ego "you" to cast off fear, stop crying, and mourn the dead and testify for history. In all three versions of his memoirs, Liao claims that he completed these two sections in the evening of June 3, or roughly eight hours before the killings of June Fourth took place $(2003,16$; 2004 a, 45; 2011, 65); this evokes a romanticist vision of poethood as marked by enigmatic prescience or hypersensitivity - and, of course, by predestined suffering. He added the following dedication to sections three and four: "To the $2 \mathbf{2 0}^{\text {th }}$ anniversary of the French Revolution, the $7 \mathrm{o}^{\text {th }}$ anniversary of the May Fourth Movement, and those who have died in the politically motivated massacre of 3 June" (Day 2005, 352n633). ${ }^{3}$

Consistent as the story is in all three versions, it is not necessarily precise in the sense of historical accuracy, especially regarding Liao's first recitation

2 When citing passages that occur in all three versions (sometimes with slight variations), I quote from Liao 2011.

3 The May Fourth Movement was an iconic moment in Chinese history, closely associated with liberation from the weight of tradition, modernization, and the emancipation of China in the modern world. It was named after student demonstrations on May 4, 1919, in Beijing. 
of the poem in the presence of others. His description of the night from June 3 to June 4 comes across as something between reality and a nightmare:

I lay in bed, but another I walked through the wall and straight into the TV screen. I pushed down [the news anchors of the China Central Television Station] Du Xian and Xue Fei to take their places ... My lips protruded into the form of a gun, shooting everyone in the audience, while military boots were trampling over my skull. I grabbed the microphone, trying to resist the invisible power that was crushing me. Then I heard [my wife] A Xia scream - she was prizing my fist open, because I had squeezed her hard on the arm and left a large bruise there.

$(2011,67-68)$

Liao also makes two retrospective comments before discussing the actual recitation. The first portrays the recitation as an instinctive act, in which his artistic drive towards self-destruction converges with a historical incident; and the second contrasts the lack of emotional expression in the historical record with the need for emotional investment in recitation $(2011,68)$. Several pages on, Liao concedes that he may have forgotten things and confused the sequence of events; and he writes that in prison, when he was interrogated, he denied Li Yawei's presence when he recorded the poem at home, and that this came close to erasing his own, actual memories (2011, 72-73). These ambiguities and ambivalences allow Liao to offer, in Alexander's terms, a tragic narrative of his trauma in relation to June Fourth, in which Liao-as-protagonist is characterized by his inability to comprehend the event and control his own fate.

Liao Yiwu describes how he saw Day pack the tapes after the recitation: "I stared at Day, who opened his big vagabond's backpack and put in these seeds of fire [火種]. This was a slow process of burning myself to death" $(2011,69)$. These sentences depict the narrator's attempt to grapple - belatedly - with his traumatic experience by trying to track down its cause. The expression "seeds of fire" is intriguing, for it creates almost an anticlimax. It evokes the familiar metaphor for ideas that start a revolution, also used in Mao Zedong's adage that “a single spark can start a prairie fire" (星星之火, 可以燎原), and thus highlights the agitational potential of the tapes and - again - their transcendence of Liao's personal situation. But the next sentence neutralizes this by pulling it closer to its original meaning to locate a tangible starting point for the destruction of the individual person called Liao Yiwu.

The same moment, however, is rewritten in the English edition of Liao's memoir, translated by Huang Wenguang, For a Song and a Hundred Songs: A Poet's Journey through a Chinese Prison: "Day, my fellow artist-protestor, 
stuffed them in his huge vagabond's backpack. We jokingly decided that these were 'sparks of fire'” (Huang 2013, 31). Not only does the sentence about self-destruction in the Chinese version disappear here, but Day, a sinologistfriend in the Chinese version, becomes a "fellow artist-protestor." Even if Liao and Day were joking, the "sparks of fire" imply that the tapes carried a message of political agitation, reinforcing Liao's image as a poet-dissident and a voice of protest. Thus, the English edition creates a progressive narrative - again, à la Alexander - of Liao's traumatic experience of June Fourth. Liao's protest against political authority then anticipates his later suffering in prison and his ultimate escape into freedom. Reviewing For a Song and a Hundred Songs, Nick Holdstock detects this logic when he points out that the narrative struggles with its own attempts "to shape Liao's life into a conventional tale of triumph over adversity" (2013). In his "Translator's Note," Huang writes that he consulted Liao extensively on the translation to make adjustments and rearrangements in late 2011 (2013, 402-403). As such, the English translation may well reflect Liao's own (re)interpretation of his autobiographical narrative and the relevant source text(s). In this sense, Liao almost assumes the role of translator himself.

A similar, progressive reading of Liao Yiwu's memoirs is offered by Romanian-German literary author and Nobel Laureate Herta Müller, in a speech delivered in Berlin for the launch of the German edition of Liao's memoir, which she describes as a "prison book" $(2012,36)$. Locating Liao's trauma in his prison experience, she downplays the first part of the book, close to a hundred pages, which displays the narrator's precarious grasp and representation of the events that led to his imprisonment. Müller compares the publication of Liao's memoir to that of Boris Pasternak's Doctor Zhivago (До́ктор Жива́го) in the Soviet era - also first published outside the author's native land - and praises Liao's powerful writing on human nature and suffering in the prisons of a state she describes as "a Maoist relic disguised as an economic miracle" (33). This implicitly contrasts the "antiquated" Maoist state with the "modern" economic miracle, suggesting the assumption of a progressive history of modernity. Müller thus celebrates Liao's success of publishing his memoir in the modern, free world (Germany) as a triumph over premodern unfreedom.

\section{Interlingual translations of "Massacre"}

To my knowledge, the first translation of "Massacre" was into English. In March 1992, Michael Day's translation of sections three and four appeared 
under the title “The Howl” (1992a) in Geremie Barmé and Linda Jaivin's New Ghosts, Old Dreams: Chinese Rebel Voices, which "explore[s] the social and cultural roots of the 1989 Protest Movement" (1992, xv); the editors came up with the title and made some other textual adjustments without contacting Day - perhaps they were unable to contact him, since his contribution had first reached them anonymously through a third party. ${ }^{4}$ Later in the same year, Day published sections three and four in Pen International: Bulletin of Selected Books (1992b) and the Sonoma Mandala Literary Review (1992c), with the latter including a brief introduction to the poet and the poem. Unbeknownst to Day, his translation of section four also appeared in Index on Censorship as "Slaughter: Part IV" (1992d). ${ }^{5}$ Over twenty years later, in 2013, Day's translation of sections three and four was attached to For a Song and a Hundred Songs, as a single, long poem, and named "Massacre" (Day 2013). In June 2019, at a book launch held in London for Love Songs from the Gulags, a collection of Liao's prison poetry in Day's translation (Day 2019), Day claimed that he had originally translated the title as "Slaughter," attributing the change to "Massacre" in For a Song and a Hundred Songs to the editors, "for reasons that have nothing to do with poetry" (a recording of the event can be viewed on YouTube [the87 press 2019]).

German translations appeared after Liao had fled from China to Germany and cover only sections three and four. Entitled "Massaker," these were included in Hans Peter Hoffmann's translation of Liao's memoir, whose publication was timed to coincide with Liao's arrival in Germany as a writer in exile in July 2011 (Liao 2012, 156). Hoffmann's translation was reprinted in 2012, with some changes, in a slim, stylish collection called Massacre: Early Poems (Massaker: Frühe Gedichte), edited by Hoffmann, in uniquely numbered copies.

As mentioned above, section three portrays a scene of violence by mixing the voices of the speaker, the perpetrators, and the victims, and section four reflects on violence and history through the eyes of the speaker, who urges his alter ego "you" to testify. Here, drawing on examples in Day's and Hoffmann's texts, especially in passages that foreground perpetrators and victims, violence and history, I will argue that trauma is at work both in the source text and in the lexical, syntactic, and prosodic choices of translators and editors to make the poem intelligible in the target language.

At the beginning of section three, “unarmed thugs" (手无寸铁的暴 徒) encounter “professional killers” (职业杀手), and this is exactly how 
Day translates these two terms. Hoffmann's translation of the latter as "Berufskiller" is also straightforward, and neither translator revises their word choice across their various publications. “Thugs” (暴徒) is a pejorative term that was used in the Chinese state media for the protesters once the crackdown had begun. Day's "unarmed thugs" effectively conveys the sense of absurdity in the oxymoronic phrase in the source text (1992c, 52; 2013, 395). Hoffmann's choice of "Unruhestifter" 'agitator', literally "creator of unrest," brings out the political awareness of the protesters $(2011,42 ; 2012,9)$.

As for other words in the source text that refer to the perpetrators, we find 㓣子手 'executioner' and 屠夫 'butcher'. Day translates both as “butcher.” Turning an executioner into a butcher draws the image away from one of authority-sanctioned killing (quite aside from its justness or the lack thereof). It also suggests dehumanization of the victims and - by invoking a colloquial use of the image - a violent cruelty on the part of the perpetrator. This shift can be read as reflecting the translator's outrage at June Fourth; while any translator could feel this, Day probably experienced June Fourth more immediately than most. That said, his translation flattens the differences between executioners and butchers.

Hoffmann uses Mörder 'murderer' for both terms in his 2011 translation, distinguishing them from his Berufskiller by removing Berufs- 'professional' and using the Germanic equivalent of the English "killer." On balance, this flattens the differences between the three source-text terms for the perpetrators even more than does Day's translation. In his 2012 version, more accurately, for the executioners and the butchers, Hoffmann opts for Henker 'executioner' and Schlächter 'butcher', now fully mirroring the source text.

Both the source text and translations evoke the global cultural trauma of the Holocaust to condemn the violence and immorality of slaughter. “Cremator” in the source text - 焚尸炉, literally “corpse-burning oven” - for example, offers an image that facilitates historical association with the Holocaust. Both Day's “cremator" (1992c, 53) and Hoffmann's “Krematoriumsöfen" (2011, 44; 2012, 11) stay close to the source text. Later Day revised his translation into the more graphic "corpse incinerator" $(2013,397)$, but for conveying the darkness of state-organized systematic killing, this is perhaps less powerful than "crematorium," which is how Barmé and Jaivin adjusted Day's translation (1992a, 102).

As with my tentative invocation of Day's personal experience of June Fourth, one might wonder if Hoffmann's background may have played a role in his strategies of translating "Massacre" at large, as a citizen of a nation and native speaker of a language that have thoroughly addressed the collective memory of dictatorship and state violence - even if, just as 
in Day's case, this remains a speculative question. In this light, Hoffmann's use of liquidieren 'liquidate' to translate the soldiers' shouts of “干掉” 'get rid of, throw out' is an interesting lexical choice. Day translates this colloquial expression straightforwardly as "do away with": "Do away with all beauty! Do away with flowers! Forests. Campuses. Love. Guitars and pure, clean air!" (1992c, 52). Hoffmann's rendition conveys the idea of killing in a technical, dehumanizing way. While there is no way of knowing the translator's intention, for the reader this word will likely recall the cultural trauma of the Holocaust.

Another interesting moment in the relation of source and target texts to the historical memory of violence and suffering appears in the translators' interpretations of 作为一次次杀翏的见证, a syntactically ambiguous phrase in section four of the poem. Day's 1992 and 2013 translations read, respectively: "[Let your sobs] ... give repeated testimony of the slaughter" (1992c, 54) and "[Let your sobs] ... give repeated testimony of the Massacre" $(2013,399)$. He interprets 杀翏 'slaughter, massacre' as specifically referring to June Fourth. Hoffmann's translation, on the other hand, links 次次 'once and again' in the source text not to the testimony but to the repeated occurrence of massacres in human history, rendering 一次次杀 翏的见证 as “Zeuge aller Massaker” 'witness of all massacres'. For the last sentence: 在这史无前例的屠杀中只有狗崽子能够幸存 'in this historically unprecedented slaughter, only dog whelps can survive', Day stays close to the source text: "In this historically unprecedented slaughter ..." (1992c, 55) and "In this historically unprecedented massacre ..." (2013, 400; sic, lowercase " $m$ "), retaining the source text's traumatized focus on the killings of June Fourth through claiming its uniqueness. Hoffmann's translation, on the other hand, omits the adjunct 史无前例的 'historically unprecedented': "Dieses Massaker überleben nur Hunde" 'Only dogs survive this massacre' $(2011,46)$. Hoffmann recalls his choice as an attempt to offer a strong final chord to the poem, ${ }^{6}$ which suggests he found this more significant than the attributive "historically unprecedented." One might ask, of course, whether the collective memory of the Holocaust might make it problematic to call June Fourth historically unprecedented. Barmé and Jaivin, on the other hand, replace Day's "spawn of dogs" (1992c, 55; 2013, 400) for 狗崽子 with the expletive "sons of bitches" (105), a highly colloquial and somewhat clichéd expression of indignation and anger.

The interlingual translations discussed above demonstrate key moments in the "movement of meaning" in cultural translation. Below, we turn to the 
ways in which Liao's recitation of his poetry bring home the performative nature of cultural communication (Bhabha 1994, 228).

\section{Transmedial performances of "Massacre"}

Peter Middleton sees recitation as molded by "the contingent relations of place, people, and history" (1998, 268). John Crespi argues that poetry recitation shows "the contingencies of poetry in living action" that "move in many directions, revealing multilayered, real-world dimensions of poetic creation and reception" $(2009,5)$. Such contingencies in (live) poetry performance are clearly in evidence in Liao Yiwu's recitations of “Massacre." In his essay “Recitation” (朗 诵), Liao says poetry recitation has saved him from mistrusting words and the nihilism he had felt as a poet since 1988 . Recitation, he writes, offers a means of deeper communication beyond written words. As great reciters of poetry he names tragic historical figures such as the aforementioned Xiang Yu and Jing Ke 荆轫, who risked his life to assassinate the powerful emperor of Qin, calling them men whose deeds corresponded to their words $(1997,49-50)$. This idea resonates with what Liao later terms "the Way of the body" (身体的道) in June Fourth: My Testimony, where he celebrates ancient philosophers ranging from Confucius 孔子 to Mozi 墨子 for their willingness and ability to put their ideas in practice $(2011,36)$. Evidently, Liao perceives poetry performance as a process of transforming the page-based text into an action undertaken by the performer, towards communication that is driven by a visceral power.

That Liao's recitation is powerful is attested by a short letter from literary critic and political dissident Liu Xiaobo 刘晓波, the 2010 Nobel Peace Prize laureate who died in custody in China in 2017, and one of the most famous survivors of June Fourth. Liu, who had returned from abroad to join the students in Tiananmen Square, was instrumental in persuading the students to leave the square and thus avoiding even greater bloodshed. Used as the preface for the Chinese (2011) and German versions of Liao's memoir, Liu's 1999 letter articulates his mortification as a traumatized survivor when he heard Liao's performance of "Massacre." He writes: "Your voice makes me wonder whether I have sufficient reason to live on ... All human beings have died, only dog whelps can survive! Am I a dog whelp?" (Liao 2011, 4).

Below, in five examples, I examine the transformation of meaning-making from the page-based text to the multimedia performance of the poem, calling attention to transmedial interactions that create a new experience of the poem, which affects the text's various manifestations when it communicates trauma across media, languages, and cultures. 
(Mis)quoting Theodor Adorno as having said that "There are no poets after Auschwitz," Liao's memoirs invoke the Holocaust in order to refer to June Fourth as a cultural trauma, foregrounding the poet as the traumatized subject (2011, 236). ${ }^{7}$ Liao was present at all the performances of "Massacre" reviewed here - as the central performer and/or as its poet-creator - and his status as a survivor of (suffering related to) June Fourth, including his exile from China, would have instilled the performances with a sense of authenticity.

As noted above, Liao Yiwu's memoir claims that the first performance of "Massacre" took place on the early morning of June 4, 1989, with Michael Day and Li Yawei present. The audio recording, which is part of the Liao Yiwu Documents contributed by Day to the Digital Archive for Chinese Studies (DACHS) and can be accessed online, lasts around twenty-eight minutes. ${ }^{8}$ The performance is structured consciously to create a sense of drama, mostly through intense, highly charged repetition. With Jean-Michel Jarre's Equinox (on a tape supplied by Day) as background music, Liao starts by imitating the orders of a military march, resonating with the start of section three, where the army is given the order to kill. Next emerges the Chinese pop song “Let the World Be Full of Love" (让世界充满爱), a charity single dedicated to 1986, the International Year of Peace, by one hundred Chinese singers, while the voices of Liao, Day, and Li become audible one after another, increasingly louder and higher in pitch, in both Chinese and, less recognizably, English : “I protest! I protest!... Protest! PROTEST!” (抗 议). Liao then solemnly reads the dedications. Throughout the poem, he performs various voices, inserting animal-like howls between the sections. The recording ends like it started, with the orders to the soldiers, the repeated "I protest! Protest!" and the dedications. Equinox sounds again and then recedes into the background, to the sound of breaking glass.

Liao freely repeats phrases and sentences for dramatic effect. The most prominent repetition - in the written text as well as in the recitation - is that of the expression "blast away" (扫射) in section three, as an order to, and an exclamation by, the soldiers. On the page it regularly repeats three times, but in his recitation Liao repeats it up to six to seven times, sometimes leading into a repetition of only the second syllable, 射 'shoot', which also connotes ejaculation. When followed by the phrase "it feels good! So good" (好过瘾啊 'truly addicting'), this creates an auditory imagination of not

7 Adorno writes: "to write a poem after Auschwitz is barbaric" (nach Auschwitz ein Gedicht zu schreiben, ist barbarisch) (1986 [1977], 30).

8 Liao 2004b. 
just rapid fire but also indulgence in (violent) pleasure. Towards the end of section three, "Let the World Be Full of Love" becomes audible again, with these lyrics: "Year after year we welcome tomorrow / And year after year we have a tomorrow." The bitter irony in the performance, of extreme expressions of violence encountering a mellifluous celebration of hope and love, appears neither in the written text nor in other recitations.

In section four, the speaker scolds his alter ego "you" for uselessly crying:

People with no understanding of the times, people in the midst of calamity, people who plot to shoot down the sun.

You can only cry, you're still crying, crycrycrycrycrycrycrycry! CRY! CRY! CRY!

(Day 1992c, 54)

But suddenly Liao inserts into the recitation: "You're crying! You're crying! You're crying! I will kill you. You're crying! You're crying! I won't allow you to cry!" Notably, in all of the written text, not a single "I" appears. So who is this "I"? The perpetrator? Or the poet entering the diegesis, indicting himself for his powerlessness by threatening to kill an alienated alter ego called "you?" Here, the poet's (reciting) voice disrupts the speaker's (written) voice.

In his memoirs, Liao describes the feeling of listening to his recording together with his friends among the sound of police-car sirens outside shortly after June Fourth as one of pride but also estrangement from his reciting self: "Although I had enjoyed [the tape] many times, the Liao Yiwu in it still made me gasp for air" $(2011,82)$. He says he walked around in Fuling with the tape, playing it for his friends whenever possible and observing their reactions. "When I saw their face turn pale, I would be flooded with emotion. I didn't want to become a hero, but when the whole world went insane, how could I control myself?" (86). At one point, his friend Zeng Lei 曾磊, who worked at a military academy in Chongqing - and would be arrested in 1990, as one of six people who were making a video version of Liao's poem “Requiem" (安魂) (Day 2005, 349n625) - encouraged him to recite naked under the spotlights of the academy's recording studio, to which Zeng had access. Liao recalls having misgivings: "The space was too big and I tried my best to fill it up ... Once I punched myself in the face so hard that it swelled up. This is how this self-important style of performance took shape, and it lasted for many years" $(2011,86)$. The tragic narrative he constructs is characterized by equivocation and alienation in his description of the period following June Fourth, especially in regard to his penchant for (spectacular) performance. 
In the English edition, however, his performances are rewritten into a purposeful use of art for protest:

I would play the 'Massacre' tape and gauge the reaction to my reading. I never intended to be a hero, but in a country where insanity ruled, I had to take a stand. 'Massacre' was my art and my art was my protest.

(Huang 2013, 41)

Here, Liao's retrospective certainty and purposefulness turn his first recitation into part of the poet's teleological journey from protesting to prevailing over state power, and make his memoirs into a performance of identity, as a dissident writer. This is also exemplified in his performances of "Massacre" for international audiences in Stockholm and at the New York Public Library (NYPL), where text and poet are recontextualized and presented as testimony literature and dissident writer in exile, respectively. In these situations, Liao's recitation wants to be what it can never be, namely the re-enactment of the un-re-enactable experience of trauma.

On the night of March 19, 2013, Liao recited "Massacre" on the Sergels public square in the Stockholm city center, together with Swedish singer Maria Rosén and Germany-based Chinese artist Meng Huang 孟煌. This recitation, available on YouTube (ddzhggchd 2013), starts with Rosén and Meng chanting in low voices, respectively, a Swedish folk song and Meng's “Letter to Liu Xiaobo in Prison” (给狱中刘晓波的信). Suddenly Liao breaks in with a repeated roar of "I protest," fiercely shaking an abacus for rhythm. This is followed directly by his sensational verbal "shooting" ("Blast away! blast away!") and the description of a bloodbath (the underlined text is only in the recitation, not in the written text):

You aren't able to pass over wall after wall of fire. Aren't able to swim across pool after pool of blood. Blood, blood, so much blood. Power will be triumphant forever.

(Day 1992c, 53)

By excerpting and rearranging the text and by reiterating images of violence (blast away, fire, blood), Liao opens his performance with a portrayal of arbitrary state violence against its helpless victims. His own physical presence on the spot - as the poet, the survivor, and the exile, the performer - reinforces the authenticity of the poem as a piece of experiential testimony to the audience passing through the public square (most of whom could not have been expected to know Chinese). 
In section four, the speaking voice reflects on the situation of "we," a pronoun that may be read as identifying all those present - the performer/ poet and the audience - in the context of oral performance. Again, Liao changes the order of the written text, and he adds new phrases (underlined below) to criticize "our" muteness:

We stand on a great road but no one is able to walk.

We stand in the midst of brilliance but all people are damned [他妈的] blind.

We stand on a great road but no one is able to walk.

We all have mouths but we are mute

Everyone is mute, everyone is mute, everyone is mute, everyone is mute...

(Day 1992c, 54)

Why is "muteness" repeated in this recitation? Given the time (early 2013) and place (Stockholm) as well as the evocation of Liu Xiaobo in the performance, it is safe to say that this performance is related to the Nobel Prize. Liu's absence from the 2010 Nobel award ceremony, symbolized by the famous empty chair, was widely cited in European mass media as an illustration of the Chinese government's dictatorial nature. (As a work of performance art, Meng sent a chair to Liu at his prison address in March 2011 - which he could not track any more once it entered China.) By drawing on Liu's reputation in relation to June Fourth, Liao and Meng call attention to their own persecution as artists by the same merciless state. By chastising "everyone" for being "mute," Liao reiterates his accusation of the Nobel committee of failing to uphold the moral responsibility of boycotting the Chinese state, an accusation that also recalls Liao and Meng's protest at the award ceremony of the Nobel Prize for Literature to Mo Yan 莫言 in December 2012 (Tao 2012).

Also in 2013, Liao recited "Massacre" at the NYPL to celebrate the launch of his memoir in the US, roughly along the lines of the Stockholm performance. His recitation, together with NYPL director Paul Holdengräber's introduction of the poem and their conversation (interpreted by Huang Wenguang), was posted on the NYPL website as video and audio files. Both Holdengräber and the title slide of the on-screen projection of the English translation claim that Liao composed "Massacre" on the morning of June 4, 1989. Moreover, in the slide the poem's dedication is changed. The victims of June Fourth are named first, and the seventieth anniversary of the May Fourth Movement is not mentioned (NYPL 2013). Presumably May Fourth would have meant little to the local audience, but its erasure is ironic, as the Movement's official historiography as a patriotic student movement 
served as a major inspiration for the 1989 student protests that ended with June Fourth. The changes therefore radically recontextualize the poem. The NYPL audience would likely have assumed that Liao wrote the poem solely in response to the June Fourth killings, confirming his identity as a dissident writer resisting a dictatorial government and hence forced into exile; they would have viewed June Fourth in light of the general image of the French Revolution as a movement in pursuit of democracy and freedom. Judging by the event's representation online, and in light of these various observations, the performance could have presented a stereotypical story of disaster-and-diaspora victimhood.

Six years later, in 2019, on the thirtieth anniversary of June Fourth, Liao performed "Massacre" together with Michael Day once again, at the London book launch mentioned above. Day read the full text in English translation while Liao interjected passages from the poem in Chinese and played various musical instruments (the 87 press 2019). If their shouts of "I protest" in Chinese and English bring to mind their previous joint performance, then here Day's role as an essential collaborator - or as Liao likes to say, as his "accomplice" - is foregrounded. In all, Day has actively and substantially participated in Liao's creative work and contributed considerably to the poem's transmedial and global circulation.

A final example reaffirms that Liao's performances of "Massacre" in transnational contexts take June Fourth beyond China's borders - this time to a country with recent memories of socialism. Actress Johanna Marx performed "Massacre" (Massaker) in German in the theater project The Bullet and the Opium: Forbidden Biographies (Die Kugel und Das Opium: Verbotene Biografien), staged in the Berlin-Hohenschönhausen Memorial in September 2016, and recorded on DVD through crowdfunding. The poem was recontextualized yet again, this time by some of Liao's non-fiction in German translation, about Chinese individuals suffering under various political campaigns in China, and by Mario Röllig's story about how he was thrown in prison for being gay in the German Democratic Republic (East Germany).

A part of the Memorial was the prison where Röllig was sent at the time and where he now acts as a witness-guide to the totalitarian past. Its grey cement walls powerfully suggest to the performers and the audience what a prison looks and feels like. All the stories are narrated in the first person by German actors and actresses, who appear in short films or on stage. One of them is Liao's own account of writing and hiding manuscripts in prison and smuggling them out, as told by Marx, with Liao Yiwu playing the flute behind her on the stage. Marx's performance of "Massacre" takes place towards the end of the program and lasts nine minutes, during which 
she holds a placard which reads, in German: "Crime: Wrote a poem." It is preceded by an excerpt of Liao's 1989 audiotape, played off-stage, where Liao's dramatic weeping voice can be heard, while Liao himself sits in the first row of the audience.

The artistic method of presenting two Liaos at the same time, one mediated in various ways and one physically present, brings to mind the Memorial's - and the (German) audience's - own history before and after 1989. Different from the estranged selves that Liao portrays in his memoirs, these two represent a consistent progression of time and history. The "I-narrative" in this theater project not only presents the interlingual translation of Liao's poem and stories, but also foregrounds the possibility of translating suffering across cultures. Röllig claims that once someone is imprisoned they will never be the same. Therefore, even though the East German regime collapsed in 1989, personal traumas of political oppression have lingered on. Thus the project suggests the possibility that individual stories and memories from two countries of the former communist bloc may communicate and merge into a shared past - which, in its turn, may produce a transnational cultural trauma in the course of time.

\section{Conclusion}

This case study of "Massacre" in English and German contexts demonstrates, through the prism of trauma, the significant role of cultural translation in building, mediating, and communicating memory and history. A traumatized subject, Liao Yiwu is both the translated and the translator, in his renaming, excerpting, rearranging, and recontextualizing of the source texts. As a translator he has interacted with other agents of the translational collective (interlingual translators, editors, award jurors, readers, co-performers, etc.) to bring on the impact of his personal trauma in relation to June Fourth, and thus to contribute to constructing June Fourth as a cultural trauma that does not stop at China's borders.

\section{Works cited}

Adorno, T. W. 1986 [1977]. "Kulturkritik und Gesellschaft" [Cultural criticism and society]. In Kulturkritik und Gesellschaft I/II: Gesammelte Schriften Band 10 [Cultural criticism and society I/II: collected writings, vol. 10], edited by Rolf Tiedemann, 11-30. Frankfurt: Suhrkamp. 
Alexander, Jeffrey C. 2004. "Toward a Theory of Cultural Trauma." In Cultural Trauma and Collective Identity, edited by J. C. Alexander, R. Eyerman, B. Giesen, N. J. Smelser, and P. Sztompka, 1-30. Berkeley: University of California Press.

-. 2004. "On the Social Construction of Moral Universals: The 'Holocaust' from War Crime to Trauma Drama." In Cultural Trauma and Collective Identity, edited by Alexander et al., 196-263.

Bachmann-Medick, Doris. 2014. "From Hybridity to Translation: Reflections on Travelling Concepts." In The Trans/National Study of Culture: A Translational Perspective, edited by D. Bachmann-Medick, 119-136. Berlin: De Gruyter.

Barmé, Geremie and Linda Jaivin, eds. 1992. "Introduction.” In New Ghosts, Old Dreams: Chinese Rebel Voices, xv-xxvi. New York \& Toronto: Random House.

Berry, Michael. 2008. A History of Pain: Trauma in Modern Chinese Literature and Film. New York: Columbia University Press.

Bhabha, Homi K. 1994. The Location of Culture. London and New York: Routledge. Caruth, Cathy. 1996. Unclaimed Experience: Trauma, Narrative, and History. Baltimore: Johns Hopkins University.

Crespi, John A. 2009. Voices in Revolution: Poetry and the Auditory Imagination in Modern China. Honolulu: University of Hawai'i Press.

Day, Michael Martin (as Anonymous), trans. 1992a. "The Howl." In New Ghosts, Old Dreams, edited by Geremie Barmé and Linda Jaivin, 100-105. New York: Random House.

一, trans. 1992b. “Slaughter 屠杀 (poem by Liao Yiwu 廖亦武).” PEN International: Bulletin of Selected Books Vol. XLII, No. 2: 92-94.

—, trans. 1992c. "Liao Yiwu and 'Slaughter' 屠杀 (essay about and translation of this 1989 poem by Liao 廖亦武)." SONOMA MANDALA Literary Review (Fall): 48-55.

—, trans. 1992d (unnamed). "Slaughter. Part IV." Index on Censorship 21 (8): 34.

—. 2005. "China's Second World of Poetry: The Sichuan Avant-Garde, 1982-1992." PhD dissertation, Leiden University. bit.ly/2GbJGst. Accessed February 20, 2018. —, trans. 2013. "Massacre." In Huang, For a Song and a Hundred Songs: A Poet's Journey through a Chinese Prison, 395-400.

-, trans. 2019. Yasuo (Liao Yiwu), Love Songs from the Gulags. London: Barque Press.

ddzhggchd. 2013. “廖亦武《大屠杀》.”Youtube, March 29. bit.ly/2YYQ6CA. Accessed March 21, 2018.

Hoffmann, Hans Peter, trans. 2011. Für ein Lied und hundert Lieder. Ein Zeugenbericht aus chinesischen Gefängnissen [For a song and a hundred songs: a testimony from Chinese prisons]. Frankfurt: S. Fisher.

—, ed. and trans. 2012. Massaker:Frühe Gedichte [Massacre: early poems]. Berlin: hochroth. 
Holdstock, Nick. 2013. "For a Song: Liao Yiwu's Prison Memoir." Los Angeles Review of Books, June 4. bit.ly/2Z7ShDY. Accessed June 10, 2018.

Huang Wenguang, trans. 2013. For a Song and a Hundred Songs: A Poet's Journey through a Chinese Prison. Boston: Houghton Mifflin Harcourt.

Liao, Sebastian Hsien-hao. 2014. "From Poetic Revolution to Nation-(Re)building: Vicissitudes of Modernity in Modern Chinese Poetry." In Modern China and the West: Translation and Cultural Mediation, edited by Peng Hsiao-yen and Isabelle Rabut, 303-326. Leiden: Brill.

Liao Yiwu 廖亦武. 1997. 〈朗诵〉 [Recitation].《山花》6: 47-53.

- 2003. 《天劫 - 八九前后的个人主义证词》 [Catastrophe: an individualistic testimony around the year 1989] (online publication in MS Word file). bit.ly/ 2Vz1XVU. Accessed March 12, 2018.

一. 2004a. 《證詞: 為中國底層賤民代言》 [Testimonies: speaking for China's subalterns] (also rendered in English in colophon as Living Testimonies: stories of people behind the bars in China [sic]). Carle Place: Mirror Books.

—. 2004b. "Liao Yiwu Audio Files." Digital Archives for Chinese Studies, Leiden Division. bit.ly/2GmOXoc. Accessed March 20, 2018.

一. 2010. 〈大屠杀(长诗)〉 [Massacre (long poem)]. 《自由写作网刊》, July 4. bit.ly/2D6GSe3. Accessed March 20, 2018.

- 2011. 《六四: 我的證詞。從先鋒派詩人到底層政治犯》[June Fourth: my testimony. From avant-garde poet to political prisoner]. Taipei:Yunchen wenhua.

—. 2012. Erinnerung, bleib ... Memory, remains ... 回忆, 仍留下... Berlin: Lieblingsbuch.

Marx, Johanna, Bettina Hoppe, and Mario Röllig. 2016. Die Kugel und das Opium: Verbotene Biographien. Ein Theaterprojekt mit Texten von Liao Yiwu (The bullet and the opium: forbidden biographies. A theater project with Liao Yiwu's texts). Berlin: Stephan-Knies-Produktion.

Middleton, Peter. 1998. "The Contemporary Poetry Reading." In Close Listening: Poetry and the Performed Word, edited by Charles Bernstein, 262-299. New York: Oxford University Press.

Müller, Herta. 2012. "Mit diesseitiger Wut und Jenseitigen Zärtlichkeiten" [With this-worldly rage and otherworldly tenderness]. In Liao Yiwu, Erinnerung, bleib ... Memory, remains ... 回忆, 仍留下..., 32-37. Berlin: Lieblingsbuch.

NYPL. 2013. "Liao Yiwu in Conversation with Paul Holdengräber." New York Public Library, June 13. on.nypl.org/2YYExez. Accessed April 5, 2018.

Rothberg, Michael. 2008. "Decolonizing Trauma Studies: A Response." Studies in the Novel 40 (1-2): 224-234.

Stiftungsrat des Friedenspreises Deutschen Buchhandels. 2012. "Der Preisträger 2012: Liao Yiwu. Begründung der Jury"[The 2012 laureate: Liao Yiwu. The jury's motivation]. bit.ly/2ULlaGs. Accessed May 21, 2018. 
Tao, Anthony. 2012. "That Streaker at the Nobel Banquet Was Artist Meng Huang, Accompanied by German Peace Prize Recipient and Chinese Exile Liao Yiwu." Beijing Cream, December 14. bit.ly/2UJbFrm. Accessed September 4, 2018.

the87 press. 2019. "Liao Yiwu and Michael Day Barque Press Launch 2019." Youtube, June 13. bit.ly/2yFKkcX. Accessed August 5, 2019.

Tong Huaizhou 童怀周. 1978. 《天安门诗抄》 [Poetry from Tiananmen]. Beijing: Renmin wenxue chubanshe.

van Crevel, Maghiel. 2017. "The Cultural Translation of Battlers Poetry (Dagong shige)." Journal of Modern Literature in Chinese 14 (2)-15(1): 245-286.

\section{About the author}

Rui KUNZE is currently a DFG-funded research fellow at the University of Erlangen-Nuremberg. Her research interests lie in Chinese literature and culture from the late nineteenth century onward. She is the author of Struggle and Symbiosis: The Canonization of the Poet Haizi and Cultural Discourses in Contemporary China (projektverlag, 2012). Her work on science fiction, the history of science, and cultural entrepreneurialism in modern and contemporary China has appeared in East Asian History, Twenty-First Century (二十一世紀), Concentric: Literary and Cultural Studies, and China Perspectives. 